\title{
Music and the Kárahnjúkar Hydropower Plant: Style, Aesthetics, and Environmental Politics in Iceland
}

\author{
This article bridges ecocriticism and popular music analysis in a close reading of \\ three examples that respond musically to environmental debates in Iceland during \\ the period 2006-2009. Political-environmental tensions in Iceland reached a \\ heated level in the mid-2000s with the construction of the Kárahnjúkar \\ hydropower project, which elicited a string of artistic and musical responses. \\ While considering Valgeir Sigurðsson's “Grýlukvæði,” Björk’s “Náttúra," and \\ Sigur Rós's "Vaka," this article argues that incorporating textual analysis and \\ interpretation is key in forging an ecocritical study of popular music.
}

Keywords: Iceland; Ecocriticism; Environment; Valgeir Sigurðsson; Björk; Sigur Rós

\section{Introduction}

In September 2006, water began to amass and slowly flood a $57 \mathrm{~km}^{2}$ area in the eastern highlands of Iceland. The artificial reservoir Hálslón was created by three massive concrete dams, drowning an area of previously uninhabited highland wilderness. The reservoir was created in order to feed the Kárahnjúkar hydropower plant, which in turn supplies electricity to Europe's largest aluminium smelter owned by the American corporation Alcoa. The construction of the entire hydropower complex involved massive industrial infrastructure responsible for considerable geomorphological change and ecological damage to the area.

The Kárahnjúkar project was the biggest industrial and infrastructural development in Icelandic history, and consequently became a much-publicized issue that attracted diverse utterances among the public. Kárahnjúkar sparked tensions and outright conflict, provoking protests from different groups of people opposing the hydropower scheme on a number of grounds; economic, cultural, and environmental. These debates bear witness to tensions in Icelandic society on environmental matters that are amplified by a history of investing the landscape with political and ideological values. By way of close reading, this article will show how music registers and reacts to such tensions at the level of style and aesthetics. 
The article contextualizes the controversial Kárahnjúkar project as the culmination of a problematic history of natural resource use in Iceland, as well as the country's economic dependency on foreign corporations in a post-colonial perspective. The article will then discuss three examples of musical response to the conflicts surrounding the hydropower developments. The musical examples discussed are Valgeir Sigurðsson’s “Grýlukvæði,” Björk’s “Náttúra,” and Sigur Rós’s outdoor performance of "Vaka" at a protest camp.

The article draws on literature dealing with music, place and identity (Whiteley, Bennett and Hawkins; Biddle and Knights), extending this line of inquiry to the questions posed in the environmental humanities (Rose et. al.; Allen and Dawe). ${ }^{1}$ Building on hermeneutic and narrative approaches to analytic methods found in popular musicology (Walser; Middleton; Hawkins, Settling; Moore; Kramer), I approach cultural analysis from the vantage point of musical texts. Cultural analysis, in this case, encompasses perspectives from ecocriticism, which expands the view of culture as mediating not only our relationships with other humans, but also with the natural environment. As such, I provide insights gained by incorporating textual analysis and close reading into ecocritical music studies (Richardson, "Closer"; Edwards, "Critical”). 2

In the context of Nordic music, Daniel Grimley has illuminated notions of nature as ideological complexities that are negotiated in performances of national and regional identities. The importance of this perspective for understanding Icelandic popular music was first demonstrated by Nicola Dibben ("Nature"), and has subsequently been explored by others (Cannady, Richardson, An Eye; Hall). This article furthers their research by addressing the Kárahnjúkar hydropower plant and its artistic responses as a detailed case study. ${ }^{3}$

The musical examples in this article are drawn from 2006 to 2009, a period in Icelandic society characterized by the contours of economic boom and crisis. Encountering this material from the perspective of a non-native researcher, this period is noteworthy for the resurgence of national-romantic landscape imagery on several fronts. Political rhetoric of the time connected the economic expansion to the "special characteristics" of Icelanders shaped by the unforgiving landscape (Loftsdóttir). The same period witnessed the growth of nature-based tourism and government initiatives for branding the Icelandic nation as "pure" and "unspoiled" (Huijbens). 


\section{Waterfalls of Trouble}

During the first decade of the twentieth century - at the height of the Icelandic independence movement - the renowned composer Sigfús Einarsson (1877-1939) published a song titled "Draumalandið" ("Dreamland"), based on a national romanticist poem of the same title. Einarsson's setting of the poem has become an Icelandic classic, widely performed as a cornerstone of the art song repertoire in the Icelandic language. The song, originally for female voice and piano accompaniment, is in romantic, AustroGerman lied style. In "Draumalandið," the beauty of the landscape is praised, a landscape to which the Icelander is forever attached: "par batt mig tryggðaband" / "That is where I am bound" (the literal meaning of tryggðaband is entering into a commitment with a lover, an engagement). In Einarsson's setting, this line is sung twice at the melodic climax, as the piano accompaniment shifts from its wide, rubato arpeggio to a more insistent hammering of chords, underscoring the political charge of this sentiment in the early twentieth century.

Ideas of nature, as treated in Iceland's strong traditions of poetry and song, has been one of the main ways of articulating the nation state since the independence movement (Hálfdanarson "Hver"). The nationalism of the early twentieth century sought to distinguish Icelandic culture from the Danish by highlighting the unique landscapes as a direct link to the independent commonwealth of the romanticized "saga age."4 Although a fully independent Republic of Iceland was not declared until 1944, a cultural trajectory that emphasized national unity was growing at the turn of the century (S. Magnason; Cannady). The landscape was seen to contain a link to the archaic and "original" Norse culture, which became a point of reference in the negotiations for becoming an independent nation. As captured in the song "Dreamland," the nationalism of the period led to a confluence of aesthetics and politics on the subject of landscape. The elision of nature and nation has proven tenacious, being re-activated in contemporary political discourse, especially on environmental issues such as the Kárahnjúkar development.

The title Dreamland appeared again a century later in a best-selling work of cultural criticism by the novelist and playwright Andri Snær Magnason (2006). Magnason's use of the title is intentionally ironic, in that it highlights the disjuncture between the sentiments conveyed in the classical song, and what he perceives as a wholesale shift to a capitalist conception of nature as economic resource. In his widely 
read book, Magnason explores the historical and ideological grounds that have prepared the Icelandic nation for fully endorsing the necessity of foreign corporations and their construction of aluminium smelters on Icelandic soil, despite Iceland's low unemployment rates and high standards of living. Magnason's polemical book, with the subtitle "A Self-help Manual for a Frightened Nation," provides an interpretation of recent Icelandic history as centered on the anxieties of a small nation eager to prove itself on the world stage. Following the financial crisis of 2008, several researchers would describe the intensified transformations of economic boom and subsequent collapse as the result of a postcolonial desire to be recognized as equals to other actors in the global financial world (see Loftsdóttir; Bergmann).

Magnason observes similar dynamics in Iceland's extensive development of hydropower industry. Ever since the onset of industrialization at the beginning of the twentieth century, the abundant water-power inherent in the country's big rivers and waterfalls was seen by the nationalist intellectuals as a key to prosperity, a way of putting Iceland on the map as a fully modernized nation among its European neighbors. The uniqueness of Iceland's topography was re-imagined as an economic resource to be harvested for the good of the nation, a symbolic stepping stone on the way to attaining a modernity that disentangled Iceland from its heritage of Danish colonial rule.

Hálfdanarson describes the dominant discourse: "it was not only the prerogative of the human inhabitants of Iceland to harness the energy of the Icelandic rivers, but it was their duty, or even their national mission" ("Sustaining" 191).

The tiny domestic energy market would never require industrialized power production of much scale, and as such, the visions of hydropowered modernity was from the beginning dependent on global energy demand. Influential ideologues, such as Jakob Björnsson, who headed the National Energy Authority (Landsvirkjun) from 1973 to 1996, laid down the framework for attracting foreign corporations involved in the aluminium industry to the island. Aluminium smelting is by far the most powerintensive industry in the world, and aluminium corporations were therefore seen as an ideal target for promotional efforts that promised "the cheapest energy in Europe" and "a minimum of environmental red tape" (Krater and Rose 312). Metal manufacturing corporations were thus brought in, while nature conservation rules were relaxed.

The development of hydropower production for the benefit of the global aluminium industry was presented by Björnsson as Iceland's only route to economic prosperity, framed as a national mission. Such a monolithic view inevitably attracted 
dispute. Yet, as Hálfdanarson points out, critics of hydropower development have also relied on nationalistic arguments ("Sustaining"). The Nobel prize-winning author Halldór Laxness expressed his highly critical views in an article titled "The War Against the Land" ("Hernaðurinn gegn landinu", 1970), where the proponents of hydropower development are characterized as enemies of the nation, a view made possible by locating the nation in nature. The subject of hydropower thus reveal how different views of nature are tied to ideological positions on Icelandicness and visions of the nation's future. This politicized rhetoric was rekindled in the 2000s during the Kárahnjúkar development and formed the target for many of the artistic utterances of the time (see Ólafsdóttir; Gremaud). ${ }^{5}$

The Kárahnjúkar project was fast-tracked by a political elite that disregarded ecological concerns. The original environmental impact assessment, conducted by Iceland's National Planning Agency, ruled against the project on grounds of permanent ecological damage. However, Iceland's then Minister for the Environment, Siv Friðleifsdóttir, famously overturned her own agency's ruling, allowing the construction to begin (Umhverfisráðuneytis). Similarly, a negative scientific report by government geophycisist Grímur Björnsson was silenced by his superior, and not disclosed to parliament before the vote on the project, as legally required ("Former").

Protests against Kárahnjúkar were not only concerned with the conservation of wilderness areas, but were rooted in the anxieties around the economic, cultural and political developments happening in Iceland at the time, which the hydropower plant came to symbolize. The project was an example of the risky, fast-paced capitalist ventures that characterized the years preceding the financial meltdown. When the construction of the project's biggest dam came to its completion in 2007, there would only be a year until the morning of October 6, 2008, when the three biggest Icelandic banks suddenly collapsed, hurling the country into crisis. The pre-crisis discourses of economic boom are thoroughly inscribed in the concrete fabric of this "humongous monster," which is how the dam was described by one of Iceland's foremost musicians, Jón por Birgisson, also known as Jónsi, of the band Sigur Rós (Heima, 56:45 - 56:50).

\section{Here Comes Grýla: Valgeir Sigurðsson, Spatiality and Vocal staging}

In 2008, the Icelandic composer and producer Valgeir Sigurðsson (b. 1971) composed the music for the documentary film, Dreamland, based on Magnason's book mentioned above. This film takes a critical perspective on the hydropower developments in 
Iceland, focusing especially on the environmental and cultural impact of the Kárahnjúkar mega-project. Dreamland takes the viewer on a cinematic journey through the landscapes of the interior highlands that are now severely impacted by industrial development. The cinematography effectively captures how, in the late 2000 s, the sudden shift in going from economic boom to total collapse was mirrored in profound physical changes to the land itself. The film culminates in a series of long and torturous shots of birds and animals struggling to cope with the flooding of the Hálslon reservoir. After this climax, the end credits appear accompanied by a piece of music, later released as a single, namely Sigurðsson's radical re-composition of an old Icelandic folk song called "Grýlukvæði” (“song of Grýla").

In Sigurðsson’s version of "Grýlukvæði," the original tune (a stepwise, pentatonic melody) is disrupted, cut-up and turned into a surreal collage of opposing musical elements. The result is an avant garde mix of styles and genres, including musique concrète, noise, and acoustic chamber music. Sigurðsson's transformation of the folk tune becomes a dialectic struggle (and ultimate synthesis) of the traditional song and the twenty-first century digital mediation, in a way that musically mirrors the troubling dialectic of nature-culture. ${ }^{6}$

"Grýlukvæði" references a folk song and the seventeenth century epic poem upon which it is based. The poem is just one of many Icelandic poems, songs, rhymes and jingles based on the folkloric character of Grýla. Grýla is a hideous, man-eating troll woman, who descends from the mountains around Christmas to capture, cook, and eat naughty children. The character is still a big part of the Icelandic Christmas celebrations (Gunnell).

The Grýlukvæði poem contains many stanzas, some widely known and others less so, describing different aspects of Grýla and her adventures. Significantly, Sigurðsson chose the first five stanzas of the poem. These describe the beauty and richness of the Fljótsdalur region in the eastern highlands, which is precisely the site of the Kárahnjúkar hydropower project, making the text resonate with an eerie geographical precision. In the poem, this land is threatened by the greed and hunger of troll-woman Grýla. In the contemporary context, Grýla comes to represent the aluminium corporation Alcoa moving in to the region. In Sigurðsson's radical setting of the poem, the formal structure and meter is obscured by the frequent cuts, jumps, and skips of the glitch-informed aesthetic. 
The poem has been recited or sung to different melodies over the centuries, and is widely recognized in Iceland as a folk song. The ÍSMUS database ${ }^{7}$ contains recordings of many different performances of the poem from 1964 to 1985 . Some of the performances conform to the melody printed in the collection Islenzk pjóðlög ("Icelandic Folksongs," porsteinsson 1906-1909), yet many do not. In the last couple of decades, different versions of "Grýlukvæði” has made frequent appearances on children's albums and Christmas compilation albums, as well as albums of folk music collections. ${ }^{8}$ The melodic setting used by Sigurðsson appears at an earlier point in the Dreamland documentary film, when a recording of an old woman singing an a cappella version of the tune appears on the soundtrack. The basic melody is as follows:

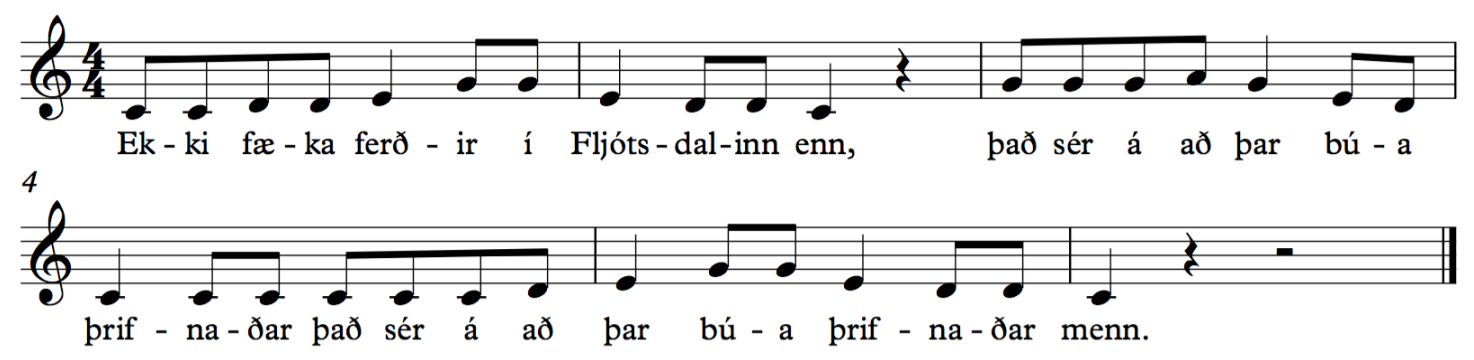

Figure 1. Pentatonic melodic setting of "Grýlukvæði," first stanza. Prose English translation: “The journeys to Fljótsdalur are not as yet diminished. One sees that people there are well-to-do.”

This melody forms the basis of Sigurðsson's setting, during which it becomes completely distorted and fragmented. It is joine by noisy textural and timbral events that move in and around the vocal line, more or less assaulting the folk song with the contemporary hiss and crackle of electronic noise. Technological treatments are pushed to extremes, making the listener aware of this track as an "impossible" performance, constructed by the cut-and-paste possibilities of digital audio workstations. ${ }^{9}$

Sigurðsson's composition transforms the tune into a statement of cultural criticism, localized in a discourse on hydropower developments in Iceland. This transformation happens mainly through three compositional strategies: (1) A surreal spatial design, (2) the synthesis of the acoustic and electronic domains, and (3) an uncanny staging of the voice. These are dealt with in turn. 


\section{Spatial design}

Sigurðsson's "Grýlukvæði” emerges as if from the ground, with the fade-in of a low drone on the double bass. The bass bows a double stopped major seventh dissonance, with a drawn-out, half-step glissando creating micro-tonal activity. The unresolved maj ${ }^{7}$ interval and tonal uncertainty of the glissando establishes an anxious mood, which is promptly contrasted by a cheerful finger-picking banjo. Already in the first few seconds of the track there is the abrupt juxtaposition of musical elements that seem completely foreign to each other. This sets the stage for the whole track, which is a collage of discrete chunks of musical material forced to coexist in the same mix.

In this collage, we hear the voice of frequent Sigurðsson collaborator Sam Amidon (discussed in more detail below) together with a solo double bass, a string section, a banjo, a piano, an acoustic guitar, a harmonium, and several types of electronic noise. The instrumental performances are treated as material for sampling: they are cut into short chunks, treated with effects and meticulously "put in their place" in the collage of the mix by way of different levels of reverberation and panning.

Each instrument is given its unique acoustic space (its own quality of reverberation) which heightens the effect of a montage assembled by bits of music from different sources smashed together on the same Pro Tools timeline. The cut-and-paste impression of the music is further enhanced by the way Sigurðsson always cuts short the decay of the reverb, avoiding the natural tail of each reverberant sound, filling the track with abrupt starts and stops. In this way, "Grýlukvæði” appears as a patchwork of unique acoustic spaces, confusing the listener's sense of a continuous spatial environment.

There is a large body of literature on sonic spatiality in recorded music, emanating from research on electroacoustic music (Smalley; Emmerson) and popular music studies (Moylan; Doyle; Moore and Dockwray; Lacasse; Moore). These theorists draw on ecological perception (Gibson; Clarke) to argue that listeners tend to perceive musical spatiality as representations of actual space, as well as constituting its own metaphoric space. On "Grýlukvæði," the spatial properties are dynamic on two levels: the individual spaces of each instrument change, as well as those spaces's position within the overall stereo field. These dynamics are continuous, accomplished using filtering automation, where levels of panning, reverberation and EQ gradually increase or decrease. The resultant sound is an impossible, or surreal, space, consisting of many dynamic rooms nested within the overall stereo field. ${ }^{10}$ 
The spatial design forms part of the composition's ecocritical aesthetics. The traditional "Song of Grýla" embodies a certain way of locating history and folklore in the landscape, representing a continuum of past and place. Sigurðsson's surreal musical space metaphorically disturbs such a stable notion of place. The spatial design thus mirrors the on-the-ground developments where industrial forces are physically altering the landscape. The degree of spatial experimentation increases towards the end of the track, as the line "There comes Grýla" ("par sé komin Grýla") is sung repeatedly. This coincides with the introduction of metallic, machine-like timbres, underscoring the analogy between the greedy troll-woman and the industrial forces.

\section{Collapse of the acoustic and electronic binary}

One of the defining characteristics of Sigurðsson's music is the blending of acoustic and electroacoustic material, often in ways that result in timbres which cannot easily be placed into either category. For the production of the Dreamland soundtrack, he mechanically prepared the grand piano in his studio with all kinds of items, only to sample it and turn it into a virtual instrument, with the samples triggered using a digital interface (V. Sigurðsson). On "Grýlukvæði," the sounds perceived as being electronically produced are actually sampled performances on acoustic instruments, treated with so much filtering that they are no longer recognized by the listener as their original sound source. Similarly, acoustic instruments are played with unusual, extended techniques in order to close in the distance between what is perceived as "natural" and "post-produced." One example is the abrupt appearance of a sustained note on the double bass at 1:05, played in an unusually high register for the instrument and bowed in a scraping fashion to bring out complex and grating overtones (see figure 2). 


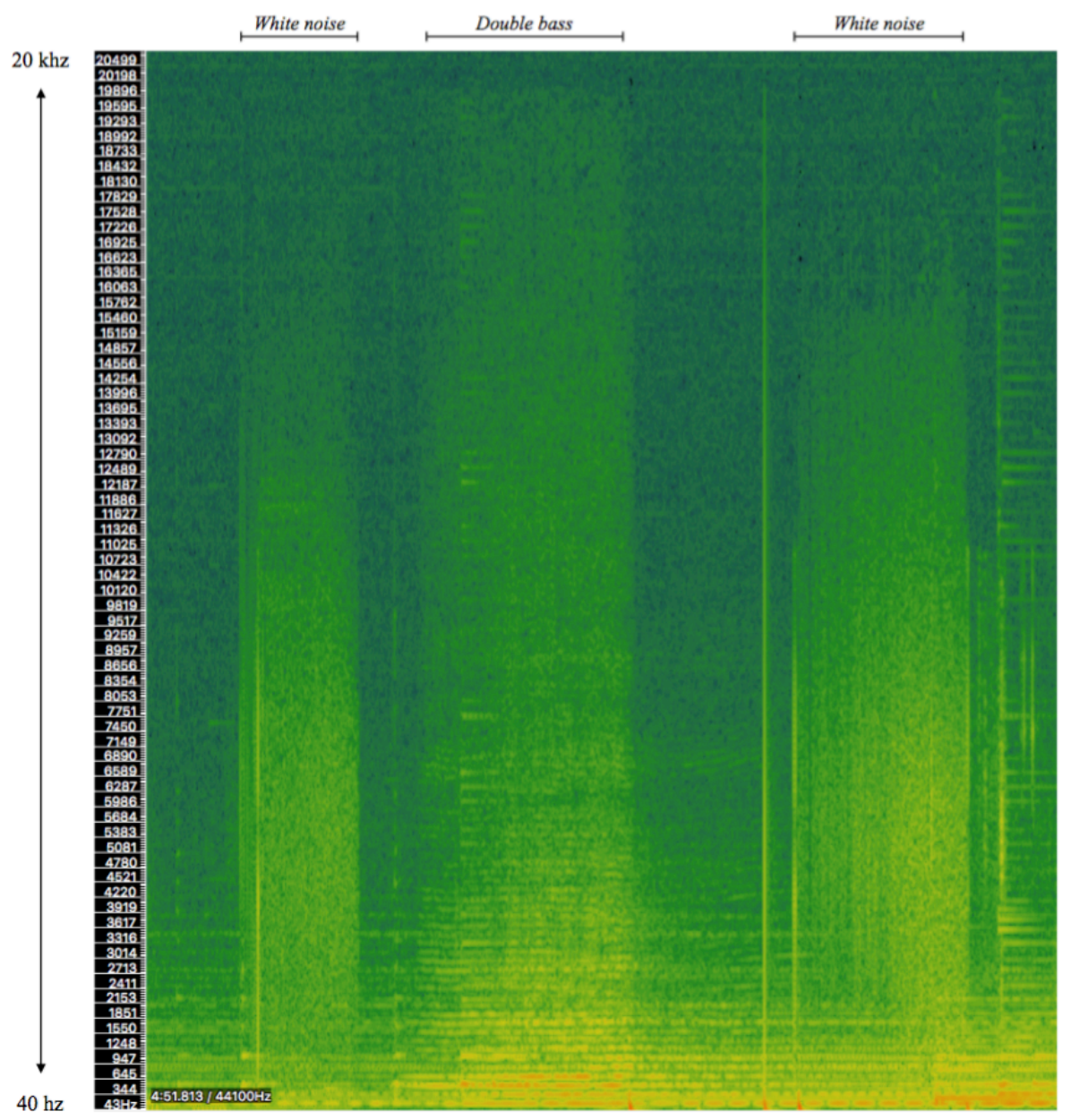

Figure 2. Spectrographic visualization of 1:04 - 1:09 of "Grýlukvæði.” Obtained using Sonic Visualiser v.2.5.

The spectrographic signature of the double bass note is in fact very similar to the white noise "shwoop" which appears directy afterwards, each sound having approximately one second duration and each containing similar amounts of acoustic energy in the same frequency ranges.

During the course of the track, what is at first experienced as acoustic instrumentation being interrupted and manipulated by electronic noise, eventually is experienced as the collapse of any clear distinction between the two. This synthesis of the acoustic and the electronic domains upsets habitual modes of relating notions of "acoustic" to "natural" (and similarly, "electronic/synthesized" to "cultural” or "unnatural"). Such problematizing of dichotomous thinking is further developed in the vocal staging on the track. 


\section{Vocal staging}

To sing the old Icelandic "song of Grýla," Sigurðsson brought in his frequent collaborator Sam Amidon, an American folk singer. Amidon's voice appears on the record as something strangely in-between the natural and the synthesized. This is an example of Sigurðsson extending his collapse of the acoustic and the electronic to the voice itself. This effect can be illuminated by looking at the technological staging of the voice on the track. Following Serge Lacasse and Freya Jarman-Ivens, I view the vocal staging as having two levels: the "internal" (or biotechnological) and the "external" (or phonographic). The internal staging of the voice is crucial here, considering the fact that Amidon is not proficient in Icelandic. As most styles of popular music rely on the singer's seemingly authentic delivery of the text, this is quite a significant point. On "Grýlukvæði," the tension resulting from the approximate pronunciation of this wellknown traditional song is exploited for an aesthetic as well as political effect.

Because of the language barrier, the recording process occurred in a start-andstop fashion, with the vocal part recorded almost word for word while Sigurðsson dictated the Icelandic text to Amidon (V. Sigurðsson). Even though the finished track adheres quite well to the normal prosody of sung Icelandic, something is clearly "off," and the vocal production makes no effort to hide it. The fragmentary appearance of the voice is rather enhanced by way of radical phonographic staging, with abrupt changes in $\mathrm{EQ}$, compression and reverb emphasizing the technological dimension of the recorded voice.

This is well exemplified at 1:08, when Amidon sings the repeated refrain of the second stanza, "Förumanna flokkarnir flykkjast pangað mest" / "the throngs of beggars flock to that place." The voice is at first characterized by a thin and distant "telephone effect" EQ setting, panned to the left and treated with a flanging effect. Yet when the line repeats at 1:12, the voice "skips" to the middle of the stereo field, suddenly at a higher volume level and a less extreme EQ setting. Such an abrupt spatial manipulation of the voice, added to the distortion of its natural timbre, destabilizes the listener's identification with the singing voice and runs counter to the ideals of authentic textual delivery in folk music genres.

Folk music derives much of its authenticity from a perceived closeness to nature (Ingram 48). The folk genre relies on unamplified, acoustic performances that communicate a sense of a romanticized, agrarian past (Richardson, An Eye 241). As such, the audible technological treatment of the voice is especially forbidden in the folk 
genre. "Grýlukvæði" seems then to be suggesting a severed connection with the authenticity of folk by exposing the agency of modern music technology. The degree of technological mediation twists and turns the "natural" folk song inside out, emerging as a critical commentary on human-environment relations in Iceland. This process is one of defamiliarization, where the well-known traditional tune is made strange, and thus provides the necessary distance for critical reflection on the issues at hand. ${ }^{11}$

The aesthetics of the uncanny are employed to great effect in this track. The eerily fragmented voice signals the familiarly human, yet in an altogether unfamiliar manner. For listeners proficient in Icelandic, Freud's original formulation of das unheimliche rings true, with Amidon's foreign pronunciation of the text being literally an "unhomely" voice. This points toward the voice as a site of cultural politics - where notions of home, belonging and the "natural" can be recast and challenged. ${ }^{12}$

The use of an American singer becomes politically charged in this context. The author of Dreamland, Andri Snær Magnason, commented on Sigurðsson’s "Grýlukvæði" as being "almost too gloomy," describing an Iceland that is "losing itself" (Magnason). Having the American singer perform the traditional folk song embodies a crisis in Icelandic subjectivity: the composition is robbing Iceland of its own voice. Magnason sees Iceland as once again a colonial subject, not of the Danish crown but of the American aluminium corporations. A review in Iceland's biggest daily newspaper, Morgunblaðið, also notes the effect of Amidon's foreign voice, describing it as "this foreign invasion into Icelandic poetry reflects the message of the film" $(\mathrm{H}$. Sigurðsson). ${ }^{13}$ This interpretation points towards the more ominous meanings of the title Dreamland, suggesting an absurd, surreal or nightmarish situation.

By transforming the traditional, folkloric song, Sigurðsson's composition introduces voices from the past to critique the present, drawing on post-colonial anxieties related to Iceland's independence. Anthropologist Kristín Loftsdóttir has showed how the present-day economic boom and collapse was dependent on social memories and articulations of the past. She states: "In Iceland, the transformation into a more globalised and neoliberal system depended on desires and dreams, which were enacted with uncritical views of modernity and Iceland's past status under foreign rule" $(341)$.

I now turn to another example of musical response to the hydropower issue, this time by Iceland's international pop icon Björk. Björk was involved in organizing several grassroots events to protest the construction of the Kárahnjúkar plant. Her 
artistic activism involved releasing a song that is significant both as a powerful statement in the local environmental debate, and as an example of ecologically informed musical aesthetics.

\section{Sonic Cascades and Metrical Ambiguity in Björk's "Náttúra"}

The cover photo for Björk's 2008 single "Náttúra" ("Nature") features the artist appearing small and insignificant next to a gigantic hurl of water crashing into the rocks at a waterfall on one of the biggest glacial rivers in Iceland. Considering Björk's previous album covers - all of them highly stylized, glossy expressions of her transgressive individualism - this photo is rather unique. Here Björk as artist is absent; all we see is an anonymous woman in everyday clothes standing off to the side. It is the river itself, or rather Björk's conception of Nature, that is the real subject of the photo (and, to an extent, the music). The location for the photo shoot was the river Jökulsá á Fljótsdal, one of two glacial rivers in the area that were dammed for the construction of the Kárahnjúkar hydropower plant, making the previously unique ensemble of waterfalls and rapids go silent.

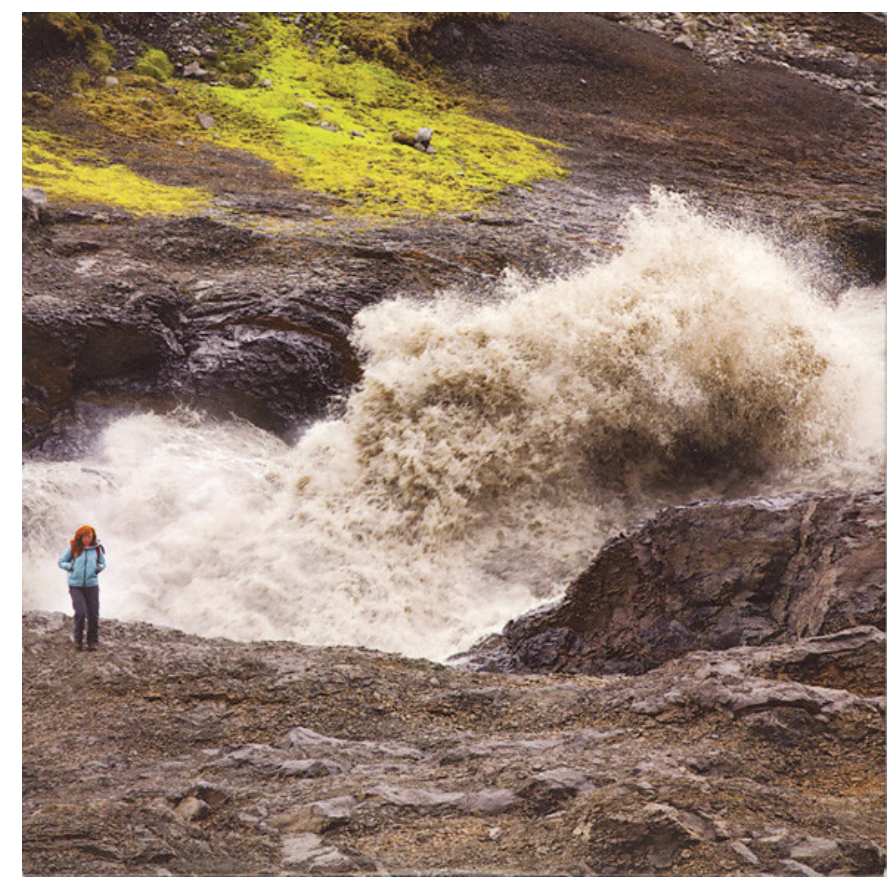

Figure 3. Cover photo of Björk’s single "Náttúra” (One Little Indian, 2008).

In 2008, Björk turned the sound back on. "Náttúra" opens with the rumbling noise of water flowing down a rocky river. This sound introduces a composition primarily 
structured around the interplay between Björk's voice and a complex, circular drum pattern. For the production of "Náttúra," Björk collaborated with the American drummer Brian Chippendale, whose performance style is characterized by maximum volume and physical intensity. The attack-heavy drums are mixed louder than Björk's voice and surrounding her on all sides of the stereo field. The musical relationship between the drums and the voice comes to signify Björk's idiosyncratic conception of the Icelandic landscape as wild, powerful and gripping. The sharp distortion of the sawtooth synth bass and the dissonant harmonic textures hark back to Björk's early career in the anarchist punk band Kukl. The track maintains a high-energy, manic feel throughout, with the insistent tone of Björk's powerful, belting voice communicating a sense of urgency.

In the opening section of "Náttúra," processed vocal samples form a haze of sound in the background of the mix. This is in fact the voice of Thom Yorke of Radiohead. Although his voice is unrecognizable on the finished track, the "feat. Thom Yorke" tag on iTunes has likely contributed to making "Náttúra" one of Björk's most downloaded songs, despite its avant garde style and Icelandic language. ${ }^{14}$

As one of the most discussed global pop artists, Björk has been studied from a variety of perspectives. ${ }^{15}$ Even though Björk has removed herself from the cover photo, it is difficult to separate the musical text of "Náttúra" from her personal narrative as world-famous pop icon. And, as Stan Hawkins warns, any "fixing" of the musical meaning in Björk's output is problematized by the layers of parody, pastiche, and playful banality that characterizes her handling and re-working of genres and stylistic codes ("Musicological"). Acknowledging this, my reading of "Náttúra" considers the track as a critical utterance situated within a local environmental debate, justified by the circumstances and features of the song's production.

"Náttúra" is just one of a handful of Icelandic songs in Björk's entire output, and the only Icelandic-language song to be released as a single. Björk intended the single to ignite awareness in Iceland of the threat posed to the interior highlands from further industrial developments by foreign corporations, with all proceeds from the single going towards a sustainability campaign co-founded by Björk ("Bjork").

"Náttúra" offers an ecological view of a human subject in the grip of forces that exceed our understanding and control. In the lyrics of the song, the narrator is "taken," she "receives" nature ("ég tek við pví"). The lyrical drama is heightened by the corporeality of the intense drum performance. In the final verse, Björk screams out 
random vowels, singing without words, as if the narrator of the song has finally been "taken" or possessed by the natural forces. Björk comments on how the song came about in a very spontaneous, improvised fashion, singing over Chippendale's drum performance: "I just sang it in one take. It's just a celebration of nature and how unpredictable it is and you cannot control it and you just have to kind of like let it fall all over you and go with it" (Philips). Towards the end of the track, the sound of the river returns, while Björk's voice fades out. The river both precedes and exceeds the human subject. The formal structure of the track thus underscores the ecological utterance of the song.

The drum pattern on "Náttúra" is composed of a repeated loop of rapid strokes that alternates between the low- and high-pitched tom-toms in a wave-like motion (see figure 4). The synth bass further emphasizes the impression of a wave, by looping a gliding figure that slides up a ninth before returning to the tonic for each looped segment. This circular pattern of drums and bass exhibits a high degree of metrical ambiguity. Upon first listening, it might suggest a $7 / 8$ meter grouped as $4+3$, yet as Björk's voice enters, the rhythm leans more towards a duple $6 / 8$ meter with the first half of each bar stretched by almost an eighth note. In fact, the meter of the track is somewhere in-between: Björk edited together bits of the improvisational drum performance to form a rhythm which does not conform to standard metrical units. Björk states how the editing process was more about "harnessing his energy and taking it in more organic units than grid units" (Philips). The result is a swirling composition that tugs at the listener's sense of beat and meter, contributing to the overall disorienting effect of the song.

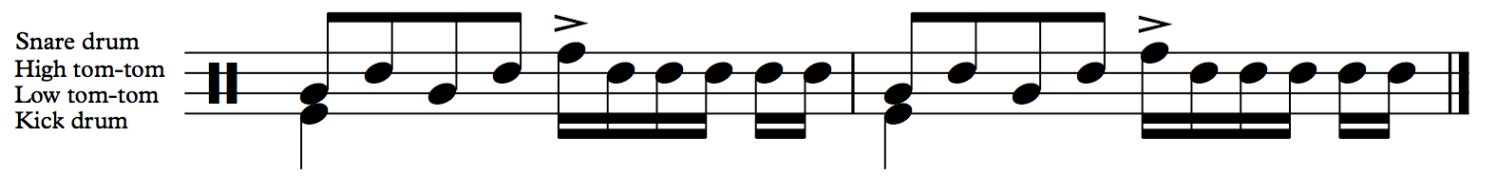

Figure 4. Repeating drum pattern on "Náttúra." Rhythmic subdivisions are only indicative.

It is interesting that Björk turns to state of the art music technology to digitally edit the live drum performance in orderto make it sound, in her words, more "organic." This is a procedure found throughout Björk's musical output, referred to by Nicola Dibben as "the naturalization of technology" and the "technologizing of nature" ("Nature" 142, 
see also Marsh and West). Björk thus challenges the convention of placing nature and technology in an oppositional dichotomy.

The textural and dynamic qualities of "Náttúra" are based on Björk's experience of the powerful sonic presence of the river. By recording the river, and incorporating its continuous rumble and circular metrics into the structure of the track, Björk is affording an artistic agency to the environment. The composition thus expresses a particular way of relating to the "liveliness" of the river by attending to its cascading motions and complex aural qualities. There is a deliberate ecological principle at work here. Rather than trying to control and harness the Icelandic landscape for human electrical needs, Björk is listening out for what it has to say - and joining in. ${ }^{16}$

By the time the "Náttúra" single was released, the Jökulsá á Fljótsdal river was already dammed and re-routed to the hydropower plant. In her correspondence with the American ecological philosopher Timothy Morton, Björk describes it as "the river that isn't”' (Guðmundsdóttir and Morton, 13). However, Björk’s environmental campaign lives on, and she is regularly involved in environmental politics and activism in Iceland. ${ }^{17}$

A third example of musical response to the Kárahnjúkar hydropower plant is the performance by Sigur Rós at a protest camp in 2006. As one of Iceland's most successful and well-known bands, Sigur Rós lent their voice to the cause by staging an acoustic performance in the middle of the wilderness area that would be flooded only weeks later.

\section{Sigur Rós's Wake for Kárahnjúkar}

During the summer of 2006, as the construction of the Kárahnjúkar project was nearing completion, environmental activists started to gather at a camp near the industrial site in the eastern highlands. By this stage, the growing protest movement against Kárahnjúkar had already become a highly musical affair, with the "Stop the dams!" (“Hætta!”) protest concert staged in Reyjavík in January of that year. The concert included performances by more than 10 Icelandic and international artists (including Björk and Sigur Rós), in front of a crowd of 5.500 people ("Hátiðarstemning"). Despite the active involvement of some of Iceland's biggest artists and the international attention brought to the issue, the political elite in Reykjavík still pushed ahead with the plans. At the protest camp in the highlands some 200 people were gathered (however, it must be kept in mind that this site is terribly inaccessible). Sigur Rós decided to join the protesters, 
who had frequent run-ins with the local landowners and the police, in the end being forcibly cleared from the premises ("Sigur").

At the time, Sigur Rós was doing a series of free concerts in small towns and villages around Iceland, which they described as a sort of "home-coming tour" after having performed in big cities all over the world (Heima, 11:20-11:25). This 2006 tour of Iceland was filmed and made into a critically acclaimed music documentary film called Heima ("At Home," 2007). Heima contextualizes the music of Sigur Rós as a way of interpreting and reflecting critically on the Icelandic landscape and the social histories that lie embedded in it. ${ }^{18}$ Here, I will not consider Heima as a whole, but rather the band's engagement with the debates on hydropower development in relation to their performance at the protest camp.

While filming Heima, the band took a detour from the scheduled route to visit the protest camp at Kárahnjúkar. In the middle of the wide, sloping wilderness of the remote highlands, Sigur Rós played an un-plugged set together with the string quartet Amiina. According to the violinist of Amiina, María Huld Markan Sigfúsdóttir, this was something that "felt very natural to do," even though they "kind of knew it was too late. We didn't expect it to stop, because the forces behind it were money and big companies" (Sigfúsdóttir). Initially the band did not want to take a stand politically, as the music was supposed to "speak for itself". However, in the words of Sigfúsdóttir: “this isn't politics, it's nature" (ibid.).

Sigur Rós catapulted into the global music consciousness at the turn of the century with their immediately recognizable musical style, often described by reference to post-rock, a sub-genre of indie rock characterized by spacious compositions that unfold in slow tempos, gradually building textural density towards a single dynamic climax. ${ }^{19}$ Sigur Rós incorporate acoustic strings in compositions that are reminiscent of minimalist orchestral music, especially the style of Arvo Pärt and Henryk Górecki, in addition to certain film music composers. ${ }^{20}$ The arguably unique aspects of the band's sound include the reverberant noise of the bowed electric guitar and the falsetto vocal idiom of singer Jónsi. ${ }^{21}$

For the un-plugged performance at Kárahnjúkar, however, the band had to adapt and come up with new arrangements for acoustic instruments (Sigfúsdóttir). This entailed a significant departure from their established musical style. The result is a soft and low-volume performance that blends into the surrounding landscape. The band intended acoustic textures as a symbolic expression of sustainability and a rejection of 
the electricity produced by the hydropower scheme. The band played along with the rustling of the wind and the distinct lack of reverb in such an open space, producing a remarkably understated and fragile vigil for the landscape that would soon disappear. ${ }^{22}$

The excerpt from this concert that appears in the Heima documentary film is the performance of "Vaka" (56:10 - 59:50). This song was originally released as the opening track of the band's 2002 album; an album that has no lyrics, no song titles, and even no album title (except for two empty brackets). The sung "text" of the song could be characterized as non-sensical vocalization. Vocalist Jónsi uses a limited set of Icelandic phonemes combined to form syllables and "words." Listening to different recordings of the same song reveals some slight variations, suggesting that there is an element of improvisation in his vocal performance. The choice of song is interesting: in such a heavily politicized context, the band decided to play a song with no semantic meanings contained in lyrics, leaving all the more room for the musical meanings to play out. $^{23}$

The song is based on a repetetive five-bar chord progression that slowly unfolds in the harmonium, vibraphone, acoustic guitar, acoustic bass guitar, and strings. The hymn-like chord progression is based upon the $\mathrm{D}^{\mathrm{b}}$ Lydian mode, starting off on $\mathrm{D}^{\mathrm{b}}$ yet modulating twice in the space of five bars, ending up on the dominant $\mathrm{A}^{\mathrm{b}}$, which has been tonicized by the preceding $\mathrm{E}^{\mathrm{b}}$. This use of a secondary dominant chord (dominant of the dominant) moves away from popular and rock harmony, entering the terrain of choral and hymnal tonal harmony in the classical Western tradition. Stepwise voice leading in the harmonium and bass, coupled with slow pacing and sustained whole notes in the strings, afford a quasi-religious mood, with the physical presence of the harmonium giving the performance a ceremonial air. 


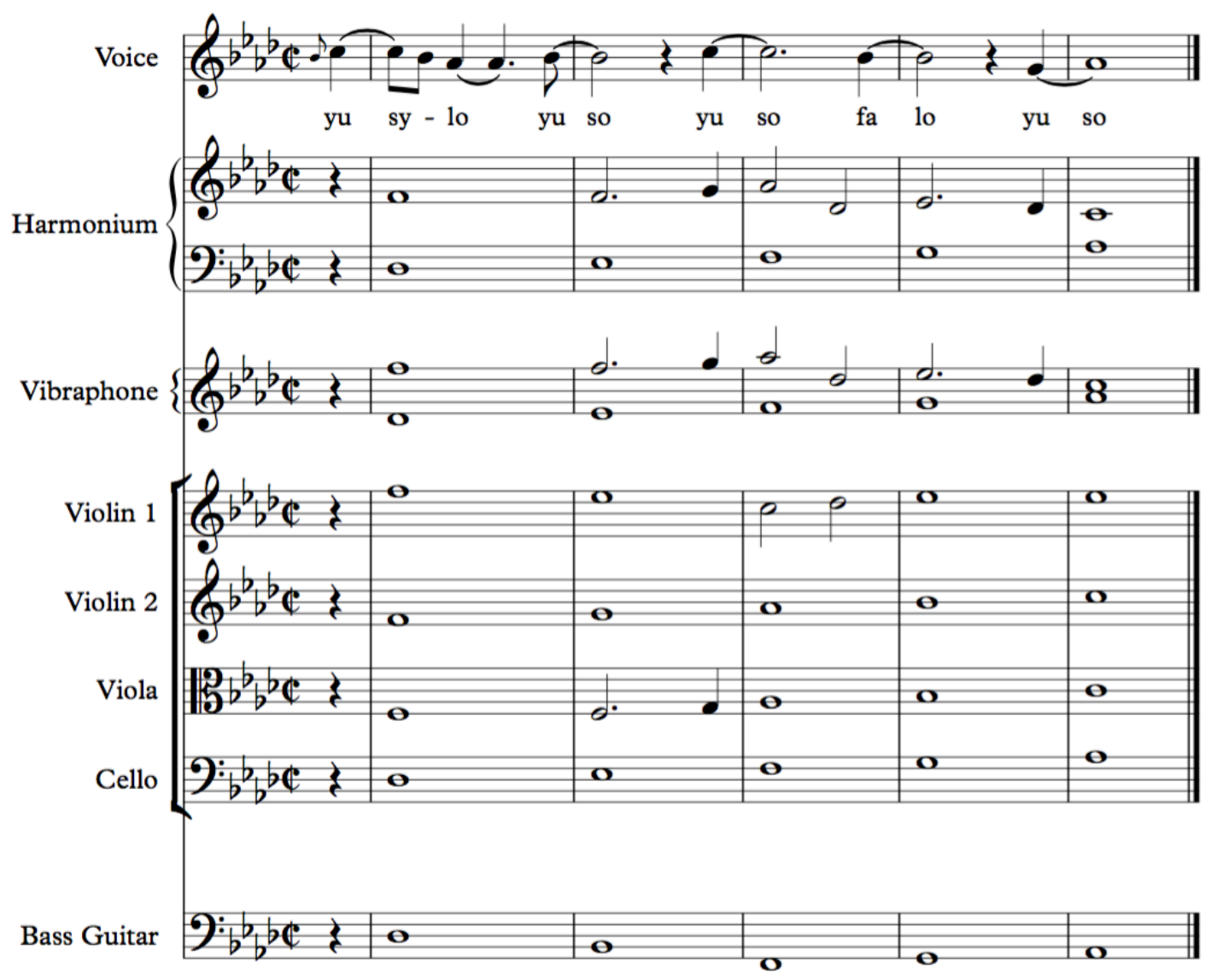

Figure 5. Stepwise voice-leading and hymnal harmony in "Vaka," exemplified by the first five bars of the first verse. Song lyrics transcribed using English phonemes.

The music is in a very slow tempo (quarter note $=40 \mathrm{bpm})$, with a lack of rhythmic events creating a sensation of suspension in-between each musical gesture. The slow churning of the cyclical chord progression comes almost to a stand-still as the construction of the hydropower plant was happening close by at an incredible speed. Several band members have described their impression of the boom period in the mid2000s as happening at an explosive tempo. Sigfúsdóttir describes the height of the boom as "everything was happening so quickly ... and all of this 'old Iceland' was getting lost by the minute." Durrenberger and Pálsson (Gambling) describes the rapid pace of industrial development in Iceland after the country's neoliberal transformations in the 1990s and 2000s. In this context, the slow tempo of the song becomes significant in itself.

The title "Vaka," considered a working title for years, only appears in print as the song was recorded in its acoustic version following the Heima tour and released on the album Hvarf-Heim ("Disappeared-Home," 2007). "Vaka" shares the same Old 
Norse root as the English "wake," and is a fitting title considering the group of protesters gathered to keep watch over a landscape soon to be sacrificed at the altar of economic growth. The song's title, in addition to the hymn-like harmonic progression and slow tempo, offers an interpretation of this performance as a lamentation for what is about to be lost. The absence of literal meaning in lyrics opens up the song, encouraging the audience to invest in it their own reflections on the political and environmental issues at hand. The slow-moving chord changes $\left(D^{b}-E^{b} s u s^{2}-F m-E^{b}-A^{b}\right)$ in 2/4 meter is stylistically as far from the traditional rock protest song as one can get, yet it clearly manages to capture the moment of lamentation and resignation. As John Richardson emphasizes, the major/minor ambiguities in this and other Sigur Rós songs performed on Heima are achieved as much by suspensions and inversions as by the chord progressions themselves, which contributes towards the contemplative mood of the music ("Closer" 175). Against the backdrop of unsustainable economic boom, the performance of "Vaka" sends a clear message of restraint.

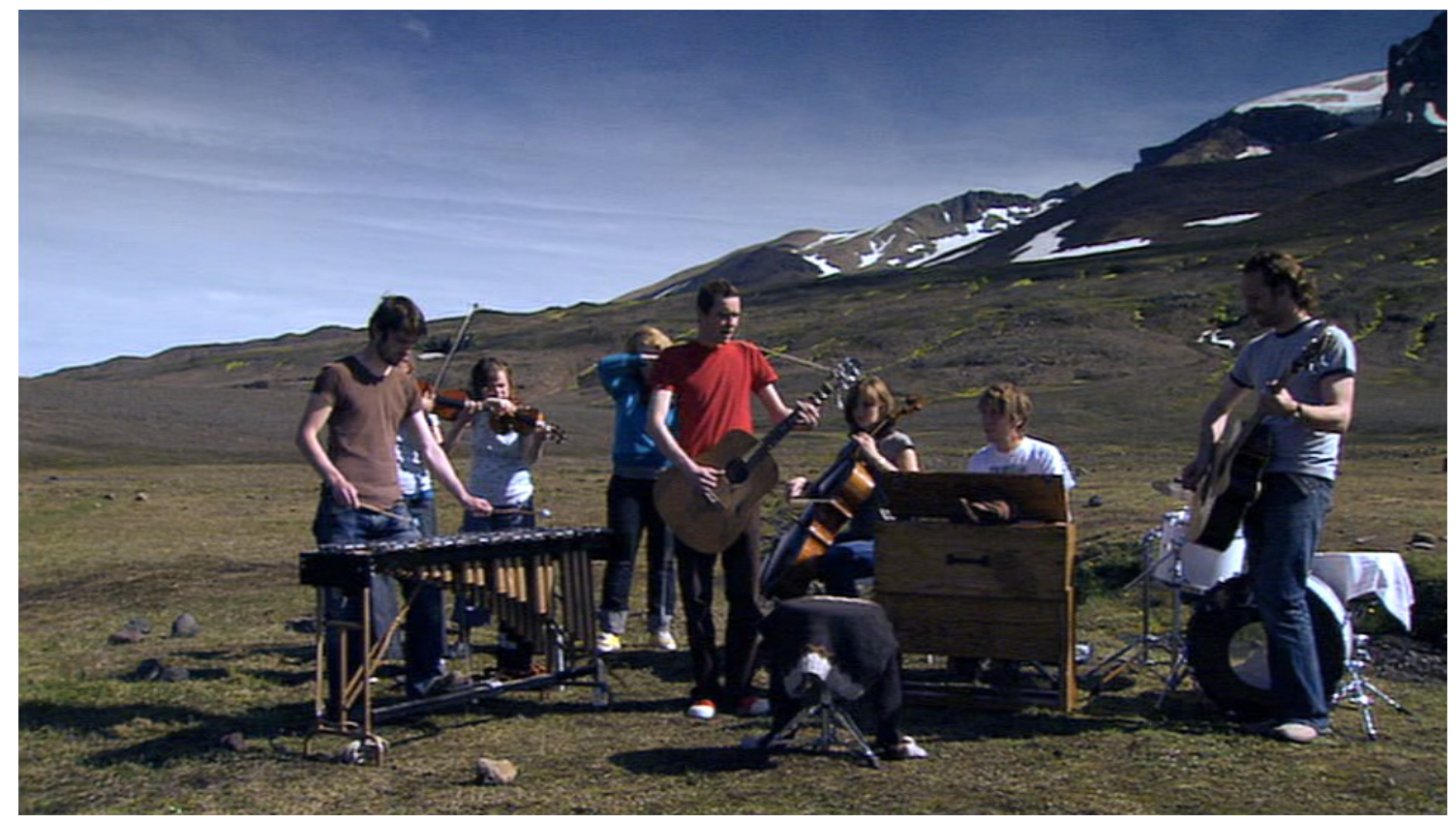

Figure 6. Sigur Rós and Amiina performing "Vaka" at the protest camp (still image from Heima).

Lawson Fletcher interprets this performance in light of a "narrative of spatial memory," which he considers as characteristicof the post-rock genre, writing how "Sigur Rós perform for a place that has a present but no future, in reference to a past that is slipping away, an 'anticipatory melancholy' that further adds to the critical form of remembering that lies at the heart of post-rock" (7). Significantly, the musical style of this 
performance, as described above, has little to do with post-rock, leaning more towards minimalist classical music in its use of repetition and chamber ensemble textures. However, the compositional and stylistic choices in "Vaka" are key to realizing Fletcher's “critical form of remembering." By employing un-plugged, acoustic instruments, the band draws on a wealth of meanings associated with "the acoustic" as a discursive construct in a digital age (Richardson, An Eye). Richardson describes this "idea of the acoustic" as standing for "the apparent sanctuary of unmediated experience in a world where technological mediation is ubiquitous" (240). The term "sanctuary" is especially productive here, as the stylistic and sonic similarities to church music are salient. The musical performance invests the highland wilderness with a certain weight and significance as ritualized space. This space allows for critical reflection on the present, by drawing musically on the past, including the somewhat anachronistic harmonic strategies employed in the song, as well as the timbre of the harmonium, which effectively evokes Iceland's rural past (Hall). ${ }^{24}$

The musical materials of the performance thus underscore a form of environmental critique that becomes effective in an Icelandic context by connecting the natural landscape to cultural heritage. There is a danger, however, that such performances perpetuate the romantic wilderness ideology that has been so effectively critiqued by William Cronon. Later ecocritics such as Timothy Morton contend that imagining Nature as romantic sanctuary upholds a distinction between humans and the environment that remains an ideological hindrance to ecological action. This performance, however, is productive as local environmental activism by directing itself to the specific issue of hydropower developments in Iceland, as opposed to an unspecified and mythologized "nature." It addresses the issue by mobilizing the affective and symbolic qualities of its musical materials that relate to senses of history, nostalgia and loss.

\section{Conclusion}

During the ten years following the completion of the Kárahnjúkar project and the flooding of the highland wilderness in which Sigur Rós performed, more hydropower schemes have been developed to serve ever more heavy industry plants on the island. In 2016 , as much as $77,3 \%$ of all electricity produced in Iceland went to the aluminium smelting industry, mostly owned by foreign corporations (Logadóttir). The profitability of these schemes is hard to gauge, as the energy prices are deemed trade secrets and 
kept undisclosed. Icelanders are kept in the dark as to whether the industrial ruin of highland ecosystems is beneficial to their nation at all. The National Energy Authority is currently not publishing reports on the profitability of the Kárahnjúkar plant (Reynisson).

These issues are not confined to hydropower, but extend to Iceland's pioneering initiatives in geothermal electricity production. Recently, there have been attempts at "induced seismic events" (man-made earthquakes) in order to produce enough geothermal energy required to meet the big contracts entered into with the aluminium industry during the boom years. The results are highly unpredictable, with residents in small towns near the geothermal plants being affected by seismic instability (Maguire and Winthereik).

Iceland continues to engineer new natural-cultural infrastructures, discovering ways to modify the landscape in order to harvest more power to serve heavy industry. Often, the environmental cost of these projects is not visible right away. For instance, the damming and re-routing of the glacial river that Björk sang with on "Náttúra" has drastically disturbed the marine ecosystems in eastern Iceland, including the biological death of Lake Lagarfljót ("Hrún"). And it is only recently that we have learnt of the importance of glacial rivers in binding $\mathrm{CO} 2$ from the atmosphere and transporting essential nutrients to ocean ecosystems (Gíslason; Eiriksdóttir et.al.).

From the opening major 7th harmonic dissonance of Sigurðsson's "Grýlukvæði," to the disorienting drum pattern of Björk's "Náttúra," the musical examples discussed bear witness to social experiences of tension and disjuncture in Icelandic society towards the end of the 2000s. The environmental critique of these songs is tied to questions regarding Iceland's global circumstances as nation state, a central anxiety throughout recent Icelandic history. When Björk states, in the foreword to the English edition of Dreamland, that politicians are "selling Icelandic nature off cheap to the industrial giants of this world," she is in fact echoing Halldór Laxness's words from half a century previously. In 1949, as Iceland was debating joining NATO and allowing the USA to build a military base on Icelandic soil, the author characterized the entire affair as Icelandic politicians "selling their country" (D'Amico 465).

The national-romantic discourse equating landscape with national heritage and historical continuity is still the primary argument for nature conservation in Iceland. Andri Snær Magnason recently likened further industrial development in wilderness areas to "someone walking around the National Museum with a sledgehammer" (qtd. in 
Logadóttir). ${ }^{25}$ This sentiment expresses a sense of loss in the face of present-day developments that are seen to threaten a unique natural-cultural heritage. Both in Sigurðsson's avant garde transformation of a traditional song and in Sigur Rós's acoustic strategies of nostalgia, there is the use of real or imaginary pasts, mobilized to critique a present perceived as disjointed.

In Iceland during the late 2000s, some of the most culturally significant voices of the population chose to address environmental issues through music. Taking this seriously, this article has employed close readings and textual analyses to highlight the unique contributions of music as a discursive form. Although the discussion has mainly focused on the Icelandic context, I have nonetheless grappled with questions of global relevance.

So far in the twenty-first century, our relationship with the natural environment remains a mediated one, structured by technology and the forms of cultural expression that surround us in everyday life. The materials of these mediations should not be underestimated, as they contribute to constructing what we imagine by "nature" and what kinds of values we attach to it. As a growing awareness of global ecological crisis seeps into artistic sensibilities and practices, musicians ask how we should best engage with our physical surroundings. The resulting aesthetics and compositional developments require further exploration by musicologists. While the uncanny voice on Sigurðsson’s “Grýlukvæði” might express gloomy alienation, Björk’s is ultimately more hopeful and radical, in singing with the landscape and providing space for attentive listening to the non-human. In the end, musical expressions such as these serve to unsettle habitual modes of relating to the environment from a position of technical mastery and dominance. 


\section{End Notes}

1. Examples of similar studies include Stimeling on music and coal mining in the Appalachian Mountains, and Guy on music and environmental imagination in Taiwan.

2. Ecocriticism, as a framework for cultural analysis, is generally characterized by the critical historicizing of "nature" and a challenging of the anthropocentricism in traditional narratives (Garrard 3). For its varied applications in music studies, see Allen and Dawe.

3. Anthropological studies on Iceland have emphasized the entanglements of "the natural" and "the social-historical" in processes of identity formation (Hastrup; Pálsson and Durrenberger). Scholars in history and geography take a similar perspective on the social and political trajectories of modern Iceland (Árnarson; Benediktsson and Lund; Karlsdóttir; Pálsson). Dibben ("Music") has studied the intersections of music and environmentalism in Iceland with reference to the hydropower industry, yet does not employ music analysis, which leaves room for the perspectives offered here.

4. The period from the age of settlement in the mid-ninth century until Icelanders came under the rule of the Norwegian king in 1264 is known as the "saga age," the glorified epoch of heroic deeds described in the famous body of literature known as the Icelandic Family Sagas (Islendingasögur).

5. Landscape aesthetics played a big part in these debates. Valgerður Sverrisdóttir, Minister for Industry during the construction of the Kárahnjúkar plant, proclaimed that the land being submerged by the dams at Kárahnjúkar was "not particularly beautiful" (“enginn serstök nátturufegurð”). This sparked a debate on what "beautiful nature" means, and if the value of nature preservation applies only to "beautiful" areas.

6. The composition relies on the common trope of noise/music as an aesthetic correlate to nature/culture in Western music aesthetics. This point has been argued by several scholars, recently by Edwards in the context of ecocritical music analysis ("Silence"). Edwards reads two of the canonical thinkers in European music aesthetics - Eduard Hanslick and Theodor Adorno - as proponents of a music philosophy in which music (belonging to culture) is the imposition of order and control onto noise (belonging to nature). 
7. ÍSMUS (íslenskur músík- og menningararfur - "Icelandic music and cultural heritage"), is a database containing recordings, texts, manuscripts, images and film pertaining to Icelandic musical heritage. The database is maintained by the Tónlistarsafn Íslands and the Árni Magnusson Institute of Icelandic Studies.

8. See, for instance, Edda Heiðrún Backmann (1991), Barnajól, PS Musík, compact disc; Eddukórinn (1991), Íslensk pjóðlög, Sena, compact disc; Prjú á Palli (1971), Hátíð Fer að Höndum Ein, SG - hljómplötum 040, compact disc.

9. This is an example of what Brøvig-Hanssen terms "opaque mediation," which she contrasts with "transparent mediation" to delineate experiences of listening to and through sound production technology ("Opaque").

10. Brøvig-Hanssen and Danielsen argue that what constitutes a surreal spatiality in recorded music is highly contextual. The effect of surreal spatial designs in music production is subject to historical processes of naturalization, in which the "surreal" becomes "naturalized" over time. However, by way of its intertextual relationship to the traditional song, "Grýlukvæði" enters into a folk music discourse privileging more natural acoustic environments, which makes the effect of Sigurðsson's compositional play of spaces far more effective. See especially Richardsson (An Eye) for discussions of the audiovisual surreal.

11. The use of "defamiliarization" here is drawing on the critical theory of Adorno, who wrote how "Perspectives must be fashioned that displace and estrange the world, reveal it to be with its rifts and crevices" (Minima, 247). Adorno was influenced by fellow Marxist Bertolt Brecht's usage of verfremdungseffektestrangement effect - in his political theatre. Brecht, in turn, was likely influenced by the German translation of Russian literary theorist Viktor Shklovsky's highly influential concept of ostranenie.

12. In popular musicology, theorizations of uncanny voices have mainly been related to queerness, see Jarman-Ivens and Hawkins (Queerness).

13. Original text: "Pessi innrás útlendingsins í íslenskan kveðskap endurspeglar í raun boðskap myndarinnar."

14. Björk and Thom Yorke famously collaborated on the Oscar-winning song "I've Seen It All” featured in Lars Von Trier's film Dancer in the Dark (2001). Regarding "Náttúra", Björk decided to ask Yorke for a contribution with the aim of maximizing exposure and to bring awareness to the issue (see Philips). 
15. This includes matters of subjectivity and identity (Hawkins "Musical", "Musicological"; Dibben "Subjectivity"). Other studies of Björk emphasize aspects of feminism and post-humanism (Marsh and West; Robbie; GoldinPerschbaker) as well as compositional practice and musical style (Dibben Björk; Malaway; Grimley; Burns, LaFrance \& Hawley).

16. This brings to mind Steven Feld's description of musical practice among the Kaluli of Papua New Guinea: "Singing about water, with water, and imagining song as water and vocal flow - here the poetry of place meets the sensuality of soundscape and the singing voice" (5).

17. Björk's artistic involvement in numerous protest activities in Iceland is discussed further in Dibben ("Music").

18. Heima has seen much attention from scholars. Porbjörg Daphne Hall views the film as an expression of nostalgia, emphasizing th cultural tensions between the rural and the urban in Icelandic society, which is similarly foregrounded by Nicola Dibben ("Nature"). John Richardson provides an in-depth analysis of the audiovisual aesthetics at work, including the use of silences and disruptions in medium-aware performances that speaks to his theorization of the audiovisual surreal (An Eye 275-281).

19. On the post-rock genre, see Hodgkinson; Hibbett; Osborn; Chuter.

20. Sigur Rós's close relationship with film music composers Jóhann Jóhannsson and Hilmar Örn Hilmarsson at the turn of the century has likely influenced their style.

21. Jónsi's iconic voice has been interpreted in terms of its androgynous qualities by Miller, who describes it by reference to the uncanny nature of the boy soprano voice.

22. While the actual performance at the protest camp, witnessed by a rather small crowd, was executed completely acoustically, the soundtrack that accompanies the performance in the film shifts halfway through to a different recording of the song made outside the band's studio. The immense electric cost of producing the finished audiovisual performance is masked behind a staged acousticness indexed by visual means, thus exemplifying Richardson's point that "acoustic music is a discourse that requires visual authentication in order to do its cultural work" (An Eye 275). 
23. The use of non-sensical vocalization in many Sigur Rós songs has been studied in terms of its lineage to dada and surrealism (Petersen; Hayden) as well as its nostalgic qualities and childlike playfulness (Richardson; Appel). It is frequently misconstrued as an invented language, due in part to the band members themselves who named it Vonlenska ("Hopelandic"). The term glossolalia is often applied, which in most cases attaches unfortunate religious baggage.

24. The harmonium was found in most churches and homes in pre-war Iceland. In 1930, there were more than 2300 harmoniums in Iceland, according to available import statistics, which is one harmonium per 40 inhabitants of the sparsely populated country. This was related in personal communication by musicologist Bjarki Sveinbjörnsson, see also Gilsson. This sheds some light on why several contemporary bands in Iceland have relied on the sound of the harmonium specifically for nostalgic effect.

25. Original text: "eins og einhver væri að ganga um Pjóðminjasafnið með sleggju.” 


\section{Works Cited}

Allen, Aaron S, and Kevin Dawe, eds. Current Directions in Ecomusicology: Music, Nature, Environment. New York: Routledge, 2016.

Adorno, Theodor. Minima Moralia: Reflections from a Damaged Life. Translated by E.F.N. Jephcott. London: New Left Books, 1974.

Appel, Nadav. “'Ga, Ga, Ooh-La-La': The Childlike Use of Language in Pop-Rock Music." Popular Music 33 (2014): 91-108.

Árnason, Porvarður. Views of Nature and Environmental Concern in Iceland. Ph.D. Thesis, Linköpings Universitet, 2005.

Benediktsson, Karl. "'Scenophobia', Geography and the Aesthetic Politics of Landscape.” Geografiska Annaler 89.3 (2007): 203-17.

Benediktsson, Karl, and Katrín Anna Lund, eds. Conversations with Landscape. Farnham: Ashgate, 2010.

Bergmann, Eirikur. Iceland and the International Financial Crisis. Boom, Bust and Recovery. New York: Palgrave Macmillan, 2014.

“Bjork Goes All 'Nattura””. Associated Press. October 23, 2008. https://www.youtube.com/watch?v=_LUKqMQB9jM (accessed August 9, 2017).

Brøvig-Hanssen, Ragnhild. "Listening To or Through Technology: Opaque and Transparent Mediation in Popular Music." In Critical Approaches to the Production of Music and Sound, eds. Samantha Bennett and Eliot Bates. New York: Bloomsbury Academic, 2018.

Brøvig-Hanssen, Ragnhild, and Anne Danielsen. "The Naturalised and the Surreal: Changes in the Perception of Popular Music Sound.” Organised Sound 18.1 (2013): 71-80.

Burns, Lori A, Marc Lafrance, and Laura Hawley. "Embodied Subjectivities in the Lyrical and Musical Expression of PJ Harvey and Björk." MTO Journal of the Society for Music Theory 14.4 (2008): 1-20.

Cannady, Kimberly D. History on Their Shoulders: Music and Nation-Building in Iceland. Ph.D. Thesis, University of Washington, 2014.

Chuter, Jack. Storm Static Sleep. A Pathway Through Post-Rock. Function Books, 2015. Clarke, Eric F. Ways of Listening: An Ecological Approach to the Perception of Musical Meaning. New York: Oxford U P, 2005.

Cronon, William. "The Trouble with Wilderness: Or, Getting Back to the Wrong Nature." Environmental History 1.1 (1996): 7-28. 
D’Amico, Giuliano. “The Whole World Is One Atom Station: Laxness, the Cold War, Postcolonialism, and the Economic Crisis in Iceland." Scandinavian Studies 87.4 (2015): 457-88.

Dibben, Nicola. Björk. Sheffield: Equinox, 2009.

Dibben, Nicola. "Music and Environmentalism in Iceland." In The Oxford Handbook on Popular Music in the Nordic Countries, edited by Fabian Holt and Antti-Ville Kärjä. Oxford: Oxford U P, 2017.

Dibben, Nicola. "Nature and Nation: National Identity and Environmentalism in Icelandic Popular Music Video and Music Documentary.” Ethnomusicology Forum 18.1 (2009): 131-151.

Dibben, Nicola. "Subjectivity and the Construction of Emotion in the Music of Björk." Music Analysis 25.1-2 (2006): 171-197.

Doyle, Peter. Echo and Reverb: Fabricating Space in Popular Music Recording, 19001960. Middletown: Wesleyan U P, 2005.

Durrenberger, E. Paul and Gísli Pálsson, eds. The Anthropology of Iceland. Iowa City: U of Iowa P, 1989.

Durrenberger, E. Paul, and Pálsson Gísli, eds. Gambling Debt: Iceland's Rise and Fall in the Global Economy. Boulder: U P of Colorado, 2015.

Edwards, James Rhys. "Critical Theory in Ecomusicology." In Current Directions in Ecomusicology, edited by Aaron S. Allen and Kevin Dawe, 153-64. New York: Routledge, 2016.

Edwards, James. "'Silence by my Noise': An Ecocritical Aesthetic of Noise in Japanese Traditional Sound Culture and the Sound Art of Akita Masami." Green Letters: Studies in Ecocriticism 15.1 (2011): 89-102.

Eiriksdottir, Eydis Salome, Eric H. Oelkers, Jorunn Hardardottir, and Sigurdur Reynir Gislason. "The Impact of Damming on Riverine Fluxes to the Ocean: A Case Study from Eastern Iceland.” Water Research 113 (2017): 124-38.

Emmerson, Simon. “Aural Landscape: Musical Space.” Organised Sound 3.2 (1998): $135-40$.

Feld, Steven. "From Ethnomusicology to Echo-Muse-Ecology: Reading R. Murray Schafer in the Papua New Guinea Rainforest.” The Soundscape Newsletter 8: 4-6 (1994). 
Fletcher, Lawson. “The Sound of Ruins : Sigur Rós' Heima and the Post-Rock Elegy for Place.” Interference Journal, no. 2 (2011): 1-11.

$\mathrm{http} / /$ www.interferencejournal.com/articles/a-sonic-geography/the-sound-of-ruins.

“Former Minister of Industry under Fire.” Iceland Review. Aug 28, 2006.

http://icelandreview.com/news/2006/08/28/former-minister-industry-under-fire (accessed March 20, 2018).

Garrard, Greg. "Introduction.” In The Oxford Handbook of Ecocriticism, edited by Greg Garrard, 1-29. Oxford: Oxford U P, 2014.

Gibson, J. J. The Ecological Approach to Visual Perception. Hillsdale, NJ: Lawrence Erlbaum Associates, 1986 [1979].

Gilsson, Guðmundur. “Harmonium.” Organistablaðið 3.3 (1970): 1-6.

Gislason, Sigurdur R., Eric H. Oelkers, and Árni Snorrason. "Role of River-Suspended Material in the Global Carbon Cycle." Geology 34.1 (2006): 49-52.

Goldin-Perschbacher, Shana. “Icelandic Nationalism, Difference Feminism, and Björk's Maternal Aesthetic." Women and Music: A Journal of Gender and Culture 18.1 (2014): 48-81.

Grimley, Daniel M. Grieg: Music, Landscape and Norwegian Identity. Woodbridge: Boydell \& Brewer Boydell Press, 2006.

Grimley, Daniel M. “Hidden Places: Hyper-Realism in Björk’s Vespertine and Dancer in the Dark." Twentieth-Century Music 2.1 (2005): 37-51.

Guðmundsdóttir, Björk, and Timothy Morton. "A philosophical email conversation between Björk and Timothy Morton" in Björk: Archives, edited by Klaus Biesenbach and Alex Ross. New York: Thames and Hudson, 2015.

Gunnell, Terry. "The Coming of the Christmas Visitors. Folk Legends Concerning the Attacks on Icelandic Farmhouses Made by Spirits at Christmas." Northern Studies 38 (2004): 51-75.

Guy, Nancy. "Flowing Down Taiwan's Tamsui River Towards an Ecomusicology of the Environmental Imagination.” Ethnomusicology 53.2 (2009): 218-48.

Hálfdanarson, Guðmundur. "Hver Á Sér Fegra Föðurland - Staða Náttúrunnar Í Íslenskri bjóðernisvitund.” Skírnir 2 (1999): 304-36.

Halfdanarson, Guðmundur. "Sustaining Economic Development or Preserving Nature? Environmental Politics in Iceland.” In The Challenge of the Baltic Sea Region. Culture, Ecosystems, Democracy, edited by Göran Bolin, Monica Hammer, Frank- 
Michael Kirsch, and Wojciech Szrubka, 189-200. Göteborg: Södertorn University College, 2005.

Hall, Thorbjörg D. 'Nostalgic Qualities in the Film Heima by the Icelandic 'krútt' band Sigur Rós.” Social Alternatives 33.1 (2014): 39-43.

Hastrup, Kirsten. A Place Apart. Oxford: Clarendon Press, 1998.

Hastrup, Kirsten. "Icelandic Topography and the Sense of Identity." In Nordic Landscapes. Region and Belonging on the Northern Edge of Europe, edited by Michael Jones and Kenneth R. Olwig. Minneapolis: U of Minnesota P, 2008.

“Hátíðarstemmning á Tónleikum í Laugardalshöll.” Morgunblaðið. Jan 01, 2006. https://www.mbl.is/greinasafn/grein/1059707/ (accessed 06.03.2018).

Hawkins, Stan. "Musical Excess and Postmodern Identity." Musiikin Suunta 21.2 (1999).

Hawkins, Stan. "Musicological Quagmires in Popular Music. Seeds of Detailed Conflict”. Popular Musicology Online 1 (2001). http://www.popular-musicologyonline.com/issues/01/hawkins.html

Hawkins, Stan. Settling the Pop Score. Pop Texts and Identity Politics. Aldershot: Ashgate, 2002.

Hawkins, Stan. Queerness in Pop Music. Aesthetics, Gender Norms, and Temporality. Abingdon: Routledge, 2016.

Hayden, Ethan. (). New York: Bloomsbury, 2014.

Hibbett, Ryan. "What Is Indie Rock?” Popular Music and Society 28.1 (2005): 55-77.

Hodgkinson, James A. "The Fanzine Discourse over Post-Rock.” In Music Scenes: Local, Translocal, and Virtual, edited by Andy Bennett and Richard Peterson. Nashville: Vanderbilt U P, 2004.

“Hrun í Lífríki Lagarfljóts.” Ríkisútvarpið. May 29, 2014. http://www.ruv.is/frett/hruni-lifriki-lagarfljots (accessed March 20, 2018).

Jarman-Ivens, Freya. Queer Voices - Vocalities, Technologies, and the Musical Flaw. Palgrave Macmillan US, 2011.

Ingram, David. The Jukebox in the Garden: Ecocriticism and American Popular Music Since 1960. New York: Editions Rodopi B.V., 2010.

Karlsdottir, Unnur Birna. "Iceland and the North: An Idea of Belonging and Being Apart." In Northscapes: History, Technology, and the Making of Northern Environments, edited by Dolly Jørgensen and Sverker Sörlin, 247-67. Vancouver: UBC Press, 2013. 
Kramer, Lawrence. Interpreting Music. Berkeley: U of California P, 2011.

Krater, Jaap, and Miriam Rose. "Development of Iceland's Geothermal Energy

Potential for Aluminium Production." In Sparking a Worldwide Energy

Revolution: Social Struggles in the Transition to a Post-Petrol World, edited by Kolya Abramsky, 311-25. Oakland: AK Press, 2010.

Lacasse, Serge. "The Phonographic Voice: Paralinguistic Features and Phonographic Staging in Popular Music Singing." In Recorded Music: Performance, Culture and Technology, edited by Amanda Bayley. Cambridge: Cambridge U P, 2010. Laxness, Halldór. "Hernaðurinn Gegn Landinu.” Morgunbladið, Dec 30, 1970.

Loftsdóttir, Kristín. "Iceland, Rejected by McDonald's: Desire and Anxieties in a Global Crisis." Social Anthropology 22.3 (2014): 340-53.

Logadóttir, Sunna Ósk. “Eigum Að Spyrna Mjög Sterkt Við Fótum.” Morgunbladið. Oct 16, 2017.

https://www.mbl.is/frettir/innlent/2017/10/16/eigum_ad_spyrna_sterkt_vid_fotum/ (accessed Mar 20, 2018).

Magnason, Andri Snær. Skype interview. 8 Feb, 2017.

Magnason, Andri Snær. Draumalandið. Sjálfshjálparbók handa hrceddri pjóð.

Reykjavík: Forlagið Bókabuð, 2006.

Magnússon, Sigurður Gylfi. Wasteland with Words - A Social History of Iceland. London: Reaktion Books, 2010.

Maguire, James, and Britt Ross Winthereik. "Living with the Earth: More-Than-Human Arrangements in Seismic Landscapes." In Infrastructures and Social Complexity: A Companion, edited by Penelope Harvey, Casper Bruun Jensen, and Atsuro Morita, 161-73. London and New York: Routledge, 2016.

Malawey, Victoria. "Musical Emergence in Björk's Medúlla," Journal of the Royal Musical Association 136.1 (2011): 141-80,

Marsh, Charity and Melissa West. "The Nature/Technology Binary Opposition Dismantled in the Music of Madonna and Björk." In Music and Technoculture, eds. René T. A. Lysloff and Leslie C. Gay. Middletown, Conn.: Wesleyan U P, 2003.

Metzer, David Joel. “The Paths from and to Abstraction in Stockhausen's Gesang der Junglinge." Modernism/modernity 11.4 (2004): 695-721.

Middleton, Richard, ed. Reading Pop. Approaches to Textual Analysis in Popular Music. Oxford: Oxford U P, 2000. 
Miller, Edward. "The Nonsensical Truth of the Falsetto Voice: Listening to Sigur Rós." Popular Musicology Online 2 (2003). http://www.popular-musicologyonline.com/issues/02/miller.html.

Moore, Allan F. Song Means: Analysing and Interpreting Recorded Popular Song. Farnham: Ashgate, 2012.

Moore, Aallan F., and Dockwray, R. "The Establishment of the Virtual Performance Space in Rock". Twentieth- Century Music 5.2 (2008): 219-41.

Morton, Timothy. Ecology Without Nature. Rethinking Environmental Aesthetics. Cambridge, Mass: Harvard U P, 2007.

Moylan, William. The Art of Recording: Understanding and Crafting the Mix. Woburn: Focal Press, 2002.

Osborn, Brad. "Subverting the Verse-Chorus Paradigm: Terminally Climactic Forms in Recent Rock Music.” Music Theory Spectrum 35.1 (2012): 23-47.

Pálsson, Gísli. Fjallið Sem Yppti Öxlum. Reykjavík: Mál og Menning, 2017.

Petersen, Emil Hjörvar. "Vonlenskan Sem Framúrstefna." Tímarit Máls og Menningur 1 (2008): 5-17.

Philips, Amy. "Björk [Part Two].” Pitchfork Date Month, 2008. http://pitchfork.com/features/interviews/7404-bjork-part-two/ (accessed March $23,2017)$.

Proppé, Hulda. “"Welcome to the Revolution!' Voting in the Anarcho-Surrealists." In Gambling Debt. Iceland's Rise and Fall in the Global Economy, edited by E. Paul Durrenberger and Gísli Pálsson, 79-92. Boulder: U P of Colorado, 2015.

Reynisson, Rúnar Snær. "Reikna Ekki Út Arðsemi Kárahnjúkavirkjunar.” Morgunbladið, Nov 30, 2017. http://www.ruv.is/frett/reikna-ekki-ut-ardsemikarahnjukavirkjunar (accessed March 20, 2018).

Richardson, John. An Eye for Music: Popular Music and the Audiovisual Surreal. Oxford: Oxford U P, 2012.

Richardson, John. "Closer Reading and Framing in Ecocritical Music Research.” In Music Moves. Musical Dynamics of Relation, Knowledge and Transformation, edited by Clarissa Granger, Friedlind Riedel, Eva-Maria Alexandra Van Straaten, and Gerlinde Feller. Zürich: Georg Olms Verlag, 2016.

Robbie, Andrew. "Sampling Haraway, Hunting Bjork: Locating a Cyborg Subjectivity." Repercussions 10 (2007): 57-95. 
Rose, Deborah Bird, Thom van Dooren, Matthew Chrulew, Stuart Cooke, Matthew Kearnes, and Emily O'Gorman. "Thinking Through the Environment, Unsettling the Humanities." Environmental Humanities 1.1 (2012): 1-5.

“Segir Engum Upplýsinum um Kárahnjúkavirkjun Hafa Verið Leynt.” Morgunblaðið April 11, 2005.

https://www.mbl.is/frettir/innlent/2005/04/11/segir_engum_upplysingum_um_kara hnjukavirkjun_hafa_v/(accessed 06.03.2018).

Sigfúsdóttir, María Huld Markan. Interview by the author. Reykjavík: 18 July, 2017.

Sigurðsson, Valgeir. Interview by the author. Aalborg: 3 Dec, 2016.

Sigurðsson, Helgi Snær. “Harmakvein Náttúrunnar.” Morgunbladið, March 25, 2010.

“Sigur Rós Plays for Protesters of Kárahnjúkavirkjun Dam," Iceland Review. Aug 3, 2006. http://icelandreview.com/news/2006/08/03/sigur-ros-plays-protesterskarahnjukavirkjun-dam (accessed March 20, 2018).

Smalley, Denis. "Spectromorphology: Explaining Sound-Shapes". Organised Sound 2.1 (1997): 35-58.

Smalley, Denis. "Space-Form and the Acousmatic Image". Organised Sound 12.2 (2007): 107-26.

Stimeling, Travis D. "Music, Place, and Identity in the Central Appalachian Mountaintop Removal Mining Debate.” American Music 30.1 (2012): 1-29. Umhverfisráðuneytis [Ministry for the Environment]. Úrskurðir Umhverfisráðuneytis [Decision of the Ministry for the Environment]. January 1, 2001: Reykjavík. https://www.urskurdir.is/Umhverfis/UrskurdirRaduneytisins/2001/01/01/nr/836 (accessed 06.03.2018).

Walser, Robert. Running with the Devil: Power, Gender, and Madness in Heavy Metal Music. Wesleyan, 1994.

Whiteley, Sheila, Andy Bennett, and Stan Hawkins, eds. Music, Space and Place. Aldershot: Ashgate, 2004. 


\section{Discography}

Björk. 2008. "Náttúra”. One Little Indian 970 TP7DL, digital mp3 single.

Sigur Rós. 2001. Ágcetis Byrjun. Smekkleysa SM79, compact disc.

Sigur Rós. 2002. (). FatCat Records FATCD22, compact disc.

Sigur Rós. 2007. Hvarf-Heim. EMI 5099950256624, 5025662, compact disc.

Valgeir Sigurðsson. 2009. “Grýlukvæði”. Bedroom Community, digital mp3 single.

Valgeir Sigurðsson. 2010. Draumalandið. Bedroom Community HVALUR08, compact disc.

\section{Videography}

Heima. 2007. Directed by Dean De-Blois. Klikk Film and Truenorth Productions, dvd. Draumalandið. 2010. Directed by porfinnur Guðnason and Andri Snær Magnason.

Ground Control Productions, dvd. 